https://doi.org/10.18485/kij.2019.66.2.7

ВЕРА П. ВАШ

Ваљевска гимназија

Ваљево
Оригинални научни рад

Примљен: 08. 04. 2019.

Прихваћен: 02. 12. 2019.

\title{
ПОЕЗИЈА КАО ФЕНОМЕН ОДНОСА ИЗМЕЪУ АУТОРОВОГ ЈА И ДРУГОГ ЈА
}

\begin{abstract}
Дефинисање појма песничког аутопоезиса, између осталих, отвара и питања као што су: Шта је, у ствари, то што називамо инспираџијом? Да ли је то исто што и ауторефлексија? Да ли је песма остварење самосвести у сопственој другости? Да ли је песник свестан те своје другости или је може спознати тек као читалац сопствене песме?

За разлику од аутопоетичких, ову врсту исказа који се дефинише као песничка самосвест није лако објаснити без залажења у когнитивно-онтолошка наличја „стиха по себи” који апстрахује сваку свест о писцу као аутору. Овде је реч о природи сопства, егзистенцијално схваћеног као емфатични облик сопственог ја, с обзиром да га пратимо у појавним облицима као што је стих.

Теорије поезије настале крајем 20. и почетком 21. века, користећи тезе данас врло распрострањене и популарне филозофије ума, имају потребу да проникну у суштину онога што филозофи подразумевају под појмом сопства, било да је реч о песми, аутору или читаоцу. Овај рад настоји да покаже у којој мери и на који начин најновије теорије имају своје претече у проучавању појма ауторовог другог ја.
\end{abstract}

Кључне речи: поезија, стих, песничка самосвест, сопство, другост, друго ја, инспирација, ауторефлексија, филозофија ума.

„Очигледно је да није лако бити велики песник” - писао је Езра Паунд, а потреба за доказивањем величине и важности је „ствар дивљачког осећања света” (Паунд 1999: 53). За руског формалисту Виктора Шкловског, поезија је истовремено и емоција и енергија, поступак „онеобичавања ствари”. Поезија, према „новокритичарима” - не „приказује”, већ „дочарава”, и као таква, нема обавезу да преноси истину, него визију. Поезија је и посебан језички израз, пун тропа, којима се, без претходне намере, управо постижу различити ефекти и нивои перцепције. Поезија је, на крају, онај „вишак” песниковог доживљаја себе,

*verav22@gmail.com 
природе, традиције и историје који се „отима” од реалног, природног и очекиваног. Вишак који се не да укротити. Вишак који је Иво Андрић крстио „демонском" везом између уметника и космоса. Представник структуралистичког приступа поезији, Џонатан Калер, поезији приписује највиши ниво екстраваганције: „Екстравагантност поезије подразумева њену тежњу према ономе што су теоретичари још у античко доба називали ,узвишено”: однос према ономе што превазилази човекове моћи разумевања, улива страхопоштовање или побуђује најбурније страсти, а говорнику ствара осећај о нечему што је изнад човека" (Калер 2009: 92).

Утилитарност естетизма за сваку врсту уметничког изражавања најјасније се рецептује управо у поезији, свеједно о којој стилској формацији је реч. Ако је симболизам „био мистични облик естетизма” (Баура 1970: 11), онда бисмо естетски принцип песништва друге половине 20. века могли назвати индивидуализованим, „онтолошким обликом естетизма”. ${ }^{1}$ Један од најзначајнијих теоретичара модерне лирике у 20. веку, Хуго Фридрих, истиче тезу о уметнику као највишем типу hoто fabera ${ }^{2}$ и поетици која је у својој основи чиста онтологија: „Слободе које себи добри лиричари узимају приликом стварања својих дела нису никаква анархија, него су промишљено мноштво значењских знакова" (Фридрих 2003: 178). Хуго Фридрих, разматрајући однос према модерности и књижевном наслеђу, у делу Структура модерне лирике износи ставове о превратничком карактеру модерног песништва у односу на класику, називајући симболички систем модерних песника аутаркичном ${ }^{3}$ симболиком: „Значења симбола мењају се од аутора до аутора, она морају да се докуче за сваког аутора посебно, а често се дешава да се уопште не дају докучити" (Фридрих 2003: 180).

Наследници симболизма, постсимболисти, као и неосимболисти, више пажње обраћају не једну другу особеност поезије својих претходника на којој је инсистирао Стефан Маларме - сугестију. У том смислу се креће и разумевање значења симбола у ових песника, акценат је на сугестивном значењу симболике песничког језика. Отуда се у другој половини 20. века детектује замах у развоју и проучавању лингвостилистичких дисциплина - фоно, морфо, синтаксо и семантостилистике. Уметнички, па тако и песнички језик је, према Јурију Лотману, другостепени, моделативни облик употребе природног језика. Уместо појма подражавање, Лотман уводи појам моделовање, јер поетски текст није проста копија (подражавање, репродукција) стварности: „, [...] књижевност има свој, само њој својствен систем знакова и правила њиховога комбиновања који служе за преношење особитих порука, које се не могу пренети другим средствима" (Лотман 1976: 54). Када се на природну језичку основу додају кодови, добија се посебна синтагматика књижевног текста. Тако се могу постићи и супрот-

\footnotetext{
${ }^{1}$ Прим. аут.

${ }^{2}$ Ковач. (досл.); стваралац (фигур.) - прим. аут.

${ }^{3}$ Самозадовољном (прим. аут.) - од аутаркија (грч. autarkeia): довољност самом себи; задовољство самим собом, самосталност: М. Вујаклија: Лексикон страних речи и израза, Просвета,
} Београд, 1980, стр. 88. 
на тумачења истог текста, заснована у доброј мери управо на сугестивном доживљају.

Велики утицај на ослобађање поезије од тематских и језичких закономерности, као и симболистичке поетике, имали су Езра Паунд и Томас Стернс Елиот. Паунд је, придајући језику највиша могућа значења и истичући пресудну улогу ритма и звука, увео тематику мисаоности и култивисаности градске интелектуалне елите. Елиот, одушевљен Паундовим поступком, продубљује тему немоћи и несавршености модерног човека и савременог света. Посвећујући Паунду једно од својих најбољих дела, поему Пуста земља, Елиот у стилском поступку иде даље од свог узора. Урушава интерпункцију и своди је на најмању могућу меру, што је тековина каснијих, футуристичких стилских поступака, користи опкорачења у грађењу стиха, неоптерећен је логиком сижејног редоследа, његови симболи су вишеслојни и хетерогени, а идејна структура захтева сложеније интелектуалне захвате. Елиотова поезија је сва у алузијама. На тај начин је ритам опстао као једна од најдоминантнијих одлика песничке поетике. „Ритам је закон стиха, према томе и закон поезије" (Солар 1971: 65).

Теорије поезије настале крајем 20. и почетком 21. века, користећи тезе данас врло распрострањене и популарне филозофије ума, имају потребу да проникну у суштину оног што филозофи подразумевају под појмом сопства, било да је реч о песми, аутору или читаоцу. Ослањају се, у највећој мери, на данас врло распрострањену и популарну тзв. филозофију ума. За разлику од аутопоетичких, ову врсту исказа, која се дефинише као песничка самосвест, није лако објаснити без залажења у когнитивно-онтолошка наличја „стиха по себи”, стиха који апстрахује сваку свест о писцу као аутору. Овде је реч о природи concmва, егзистенцијално схваћеног као емфатични облик сопственог $j a$, с обзиром да га пратимо у појавним облицима као што је стих. Самосвест као облик имплицитног знања о себи подлеже разматрањима на тему узрока тим имплицитним знањима, а то бисмо једноставно могли назвати инспирацијом.

У Феноменологији духа, која је засигурно, бар у Европи, означила сасвим нови приступ свакој духовној творевини, па и поезији, дијалектика Фридриха Хегела подразумева јединство свести, самосвести и ума. Али, истина се остварује једино у самосвести: „[...] самосвест јесте рефлектирање из бића чулнога и опажајнога света, те у суштини представља враћање из другобивства" (Хегел 1979: 105). У том другобивству, самосвест је изгубила саму себе истовремено укидајући тај чулни свет јер види саму себе у том свету. Зато мора да укине то своје другобивство и једино тако се може вратити у саму себе. Дакле, могли бисмо да закључимо да је самосвест кретање између ниже и више фазе сопства. Век и по касније, чини се да Гастон Башлар, објашњавајући појам доживљавања бивства, каже то исто, само једноставније и не упуштајући се у онтолошка разматрања природе тих процеса: „Ако смо затворени у бивство, мораћемо увек да из њега излазимо. А тек што смо из њега изишли, мораћемо увек да се у њега вратимо. Тако је у бивству све круг, све је скретање, враћање, разилажење, све је низ боравака [...]" (Башлар 1969: 267). 
Ако Бартову тезу о смрти аутора: „, [...] ако писању треба дати будућност, морамо одбити мит: рођење читаоца мора бити по цијену смрти аутора"4 повежемо са тезом Октавија Паза о искуству песме, тезом по којој се догађа „њено поновно стварање читањем или рецитовањем” (Паз 1979: 31), онда то имплицира да бисмо, осим о песничкој, могли размишљати и о читалачкој самосвести. И у једном и другом случају се покреће оно најличније своје, и у једном и у другом случају је сопство заинтригирано нечим што можемо представити као autopoesis, самостварање, само што су последице различите. У првом настаје песма, а другом тумачење. Доживљај који је узроковао покретање аутопоезиса различит је у зависности са чије позиције га посматрамо.

О парадоксу феномена читалачке самосвести пише Тихомир Брајовић у књизи Нариисов парадокс, сугеришући да тај феномен друге стране огледала (подв. В. В.) интригира сваког иоле (само)одговорног песника. Наводећи примере од чувеног Бодлеровог обраћања читаоцу, преко Борхесовог доживљаја поезије као својеврсног дуалитета писања и читања и Павићеве теорије о умећу читања као предуслову за creator mundi (подв. В. В.), па све до неоавангардних и постмодерних поета, Тихомир Брајовић закључује: „Читалац је, другим речима, постао један од нових, изразитих културних јунака нашег доба" (Брајовић 2013: 373). Именујући рефлексивним идентитетом последице, тј. резултате тог својевољног пристајања читаоца на перманентну идентификацију са оним што чита, Брајовић истиче њихову променљивост у односу на чврсто укорењене моделе наративних идентитета.

Дебора Форбс, ${ }^{6}$ упоређујући проблем самосвести у британској романтичарској поезији и америчкој поезији средине 20. века, истиче као главно питање - проблем искрености: „The problem of sincerity is central to the questions that the experience of self-consciousness raises [...]"7 (Форбс 2004: 191). Тај проблем, осим у песнику, рађа дилему и код читалаца. На крају, Дебора Форбс закључује: „Тһе reader's and the poet's senses of what has just happened are strikingly different" (Форбс 2004: 29).

Појам песничког аутопоезиса неминовно отвара питања као што су: Где песма настаје? Кад? Зашто? Ко је одговоран за њено значење? Шта је, у ствари то што називамо инспирацијом? Да ли је то исто што и ауторефлексија? Да ли се кроз њих, или помоћу њих, испољава песничка самосвест? Да ли је песма остварење самосвести у сопственој другости? Да ли је песник свестан те своје другости или је може спознати тек као читалац сопствене песме? Октавио Паз, на пример, у другости види суштину човека као бића, а „инспирација је испоља-

\footnotetext{
${ }^{4}$ http://polja.rs/1984/309-2/pdf стр. 450.

${ }^{5}$ Стваралац света (лат.).

${ }^{6}$ Deborah Forbes: Sincerity's Shadow: self-consciousness in British Romantic and mid-twentiethcentury American poetry, 2004.

${ }^{7}$, „Проблем искрености је централно од свих питања које искуство самосвести намеће” (прев. В. В.).

${ }^{8}$ „И чула читалаца, и чула песника о томе шта се управо догодило, упадљиво су различита [...]" (прев. В. В.).
} 
вање другости која је у бити човека" (Паз 1979: 181). Није у човеку, већ је то човек сам, његово биће по себи. Зато Октавио Паз сматра да: „Инспирација је хитнути се ка постојању и, такође и изнад свега, сећати се и поново бити. Вратити се Бићу" (Паз 1979: 183).

Наратив као потврда постојања уопште и наративни идентитет као потврда осмишљеног постојања у себи сажимају и рефлексивни идентитет као свој онтолошки део. Да ли то можемо сматрати самосвешћу, сопством које постоји независно од наше свести о томе?

Овај проблем Сабина Колш Фојзнер у тексту The Mental Context of Poetry, објављеном у зборнику Theory Into Poetry: New Approaches to the Lyric ${ }^{9}$ (Teoрија у поезији: Нови приступи лирици) поставља у центар својих одговора на питања зашто савремена филозофија ума обраћа тако мало пажње на поезију. Њен одговор је: "The answer involves two aspects: (a) postmodern axioms about the death of the author, and (b) a fear of fiction pervading philosophy of mind" (Колш-Фојзнер 2005: 60). Дакле, „кривци” су, с једне стране, постмодернистичке теорије о смрти аутора, а са друге, филозофију ума прожима страх од фикције. Не полемишући превише са ставовима Ролана Барта (Смрт аутора, 1968) и Мишела Фукоа (Шта је аутор, 1969), превратничким и иновативним за шездесете године прошлог века које су покренуле лавину нових теорија о егу, сопству и другом ја, Сабина Колш-Фојзнер истиче појаву збирке есеја немачког књижевног теоретичара Фотиса Јанидиса - Return of the Author (1999) у којој се реконцептуализује појам аутора у смислу комерцијалне категорије, као носиоца ауторских права, или као симптом савременог идентитета култа. Сабину Колш-Фојзнер интересује појам фикције који се мора узети у обзир приликом сваке расправе о концепту идентитета с обзиром на распрострањеност и улогу маште у савременој култури виртуелних уметничких светова. У ту сврху, она користи ставове америчког филозофа Даниела Денета о теорији поетске свести, где се појам интенционалности тумачи пре свега као ментална или контекстуална, а не лингвистичка категорија. И песма је говорни чин, па се, као и сваки други говорни чин, односи на ум и свест. Из тога произилази да је наше сопство центар наративне гравитације, наратив који је препознатљив само преко себе самог. Поезија је један од тих наратива јер не постоји „,non-narrative alternative to poetry" ${ }^{10}$ (Колш-Фојзнер 2005: 71).

На почетку своје студије, Сабина Колш-Фојзнер наводи и циљ истраживања: "The aim of the present paper is to explore the nexus between mind and poem"11 (Колш-Фојзнер 2005: 59). Истражујући везу између ума и песме, она анализира најпре разлику између емпиријског и биографског себе, а затим песничког и језичког себе у личности аутора. Фокусирајући се на појмове аутокреације и наративног сопства, доказује да ментални контекст поезије, њен етички контекст

\footnotetext{
${ }^{9}$ Theory Into Poetry: New Approaches to the Lyric (edited by Eva Müller-Zettelmann, Margarete Rubik), Rodopi, Amsterdam - New York, 2005 (57-79).

${ }^{10}$ „ненаративна алтернатива поезији” (прев. В. В.).

${ }^{11}$ „Циљ овог рада је да објасни везу између ума и песме” (прев. В. В.).
} 
(ethos), у интеракцији са културним и естетским конвенцијама (mode), добија своју потврду и актуелност у индивидуалном гласу аутора (voice).

О (не)важности ауторовог гласа је, пола века пре Сабине Колш-Фојзнер, писао Мишел Фуко у свом есеју Шта је аутор (1969), наводећи оно што су, по његовим речима, критика и филозофија већ приметиле: „, [...] суштина није у томе да се испољи и узвиси чин писања, нити у томе да се неки сиже удене у оквир језика; ради се пре о стварању простора у којем онај ко пише беспрестанце ишчезава"12.

Оно што нам се чини занимљивим, то је да се својеврсна најава улоге аутора, његове одговорности и (само)свести, пре свих модерних теорија о овом питању с краја 20. и почетка 21. века, и пре есеја Барта и Фукоа с краја шездесетих година прошлог века, већ догодила појавом есеја Традиција и индивидуални таленат Томаса Стернс Елиота 1919. године. У овом есеју, разматрајући неминовност дефинисања песниковог односа према прошлости, Елиот наводи да сваки песник поништава своје $j a$, стављајући се у службу виших циљева, тј. очувања и неговања традиције, што доводи до деперсонализације аутора: „Тако настаје једно трајно подчињавање свога ја, онаквог какво је у неком одређеном тренутку, нечему вреднијем. Прогрес уметника је трајно саможртвовање, трајно поништавање сопствене личности. ...Поезија није пуштање на вољу емоцији, већ бежање од емоције; она није израз личности, већ бежање од личности. Али свакако, само они који имају своју личност и своје емоције знају шта значи желети да се побегне од њих"13.

Једно је сигурно: нема поезије без аутора, нити песника без песме. Сложићемо се са Перси Биш Шелијем који у свом чувеном есеју Одбрана поезије (1821) песника дефинише као онога ко разуме истину и лепоту у односу између постојања, запажања и изражавања.

\section{ЛИТЕРАТУРА}

Баура 1970: Баура, С. Морис, Наслеђе симболизма / Стваралачки експеримент, Београд: Нолит.

Башлар 1969: Bašlar, Gaston: Poetika prostora, Београд: Култура.

Брајовић 2013: Brajović, Tihomir, Narcisov paradoks, Београд: Службени гласник.

Денет 1992: Dennett, Daniel C: Consciousness Explained, Penguin: Harmondsworth.

Елијаде 2015: Elijade, Mirča, Slike $i$ simboli, Београд: Фактум.

Калер 2009: Kaler, Džonatan: Teorija književnosti, Београд: Службени гласник.

\footnotetext{
${ }^{12}$ Мишел Фуко: Šta je autor? часопис Поља, Културни центар Нови Сад, 2012/473, стр. 100-112.

${ }^{13} \mathrm{http} / / /$ docslide.us/documents/t-s-eliot-tradicija-i-individualni-talenat-55844c0974c52.html
} 
Лотман 1976: Лотман, М. Јуриј: Структура уметничког текста, Београд: Нолит.

Паз 1979: Paz, Oktavio: Luk i lira, Београд: Вук Караџић.

Паунд 1999: Паунд, Езра, Како да читамо (Литерарни есеји Е. Паунда избор, превод са енглеског и предговор Милован Данојлић), Ваљево: Интелекта.

Рифатер 2006: Рифатер, Мишел: Семантика песме, Београд: Београдски књижевни часопис, II /2 (199-215).

Солар 1971: Солар, Миливој: Питања поетике, Загреб: Школска књига.

Фридрих 2003: Фридрих, Хуго, Структура модерне лирике, Нови Сад: Светови.

Хегел 1979: Hegel, G. V. Fridrih: Fenomenologija duha, Београд: БИГЗ.

\section{Публикације доступне на интернету:}

Барт: Roland Barthes: Smrt autora, часопис Поља, НИШРО „Дневник” Нови Сад, 1984/309 (стр. 450, прев. М. Бекер) 22.5.2016, http://polja.rs/1984/309-2/pdf

Елиот: Thomas Stern Eliot: Tradicija i individualni talenat (прев. М. Михаиловић) 22.5.2016. http://docslide.us/documents/t-s-eliot-tradicija-i-individualni-talenat-55844c0974c52.html

Колш-Фојзнер: Sabine Coelsch-Foisner: The Mental Context of Poetry, Theory Into Poetry: New Approaches to the Lyric (edited by Eva Müller-Zettelmann, Margarete Rubik) Rodopi, Amsterdam - New York, 2005. 26.5.2016, https://www.amazon.com/ Theory-into-Poetry-Internationale-Literaturwissenschaft/dp/9042019069/ref=sr_1_1 $? \mathrm{~s}=$ books\&ie $=\mathrm{UTF} 8 \&$ qid $=1483586534 \& \mathrm{sr}=1-1 \&$ keywords $=9789042019065$

Форбс: Forbes, Deborah: Sincerity's shadow: self-consciousness in British Romantic and mid-twentieth-century American poetry, Harvard University Press Cambridge, Massachusetts, and London, England, 2004. 28.5.2016, https://www. amazon.com/Sinceritys-Shadow-Self-Consciousness-Romantic-Mid-Twentieth-Century/dp/0674011880

Фуко: Michel Foucault: Šta je autor? - часопис Поља, Културни центар Нови Сад, 2012/473 (стр. 100-112, прев. Е. Прохић) 30.5.2016, http://polja.rs/2012/473-2/pdf

Тејлор: Charles Taylor: Knowledge and the Self: Charles Taylor's Sources of the self 30.5.2016. http://www.sunypress.edu/pdf/60558.pdf

Шели: Persi Biš Šeli: Odbrana poezije - Scribd 1.6. 2016, https://www.scribd.com 
Vera P. Vaš

\title{
POETRY AS THE PHENOMENON OF AN AUTHOR'S SELF AND AN AUTHOR'S ALTER EGO RELATION
}

\author{
Summary
}

Among others, the poetic autopoiesis concept defining opens up questions such as: What is, in fact, what we refer to as inspiration? Is it the same as self-reflection? Is the poem the selfconsciousness realization in its own otherness? Is a poet aware of the otherness of his own Self or is he able to perceive it only by reading the poem he wrote himself?

Unlike the autopoietic ones, this type of statement, which is defined as a poetic self-consciousness, is not easily explainable unless we tackle the cognitive-ontological ,verse itself" background which completely excludes the awareness of each writer as an author. This is related to the character of the Self, which is being understood as an emphatic form of one's Self, given we analyze it in different forms it may appear in such as a verse.

Having been using the thesis that are being widely used nowadays together with popular philosophy of mind, the late 20th and the early 21 st centurypoetry theses need to get to the very essence of what philosophers call the concept of Self, regardless of whether it is a poem, author or reader. This paper tackles to what extent and in what way the latest theories have their precursors in the study of the author's alter ego concept studying.

Key words: poetry, verse, poetic self-awareness, the Self, otherness, the other me, inspiration, self-reflection, philosophy of mind. 